\title{
Native Americans - from compensation to casinos
}

\section{By Gunlög Fur, associate professor of history}

\author{
Presentation of the author
}

I have chosen to define the beginning and end points of my paper by the words compensation and casinos. Partly because of the alliteration, but mostly because they illustrate to some extent changes in American Indian country in the period since the end of World War II. Much of the white political agenda of the 50s and 60s concerned offering compensation to Native American tribes for lands lost and deplorable social and economic conditions. In this framework Native peoples were still seen as passive objects of state policies. The casinos, on the other hand, represent Native American agency to a much greater extent, people ready to take advantage of the peculiar situation in which centuries of negotiations had placed them - thus a shift from termination to self-determination.

In 1946 congress enacted the Indian Claims Commission with the express purpose of ending once and for all government debts to Indian nations so that the federal government could get out of its responsibilities and start treating Native peoples like anybody else. Assimilation into the dominant culture was the goal - as so many times before compensation, termination and relocation were the means. Elimination involved ending the special legal status of tribes and instead subjecting Native Americans to state and local authorities and relocation involved the movement of Indians from reservation to cities.

Being wards of the federal government has not been a particularly enviable position, being subject to state laws was seen as an even greater threat as interaction with local (white) neighbors has often been fraught with conflict and Indians subjected to blatant racism (such as when notices outside bars and restaurants may read: "Indians and dogs not welcome"). But the vascillations between dependence as wards of the federal government and independence as autonomous tribes have been a constant feature of American policies towards its Native peoples. The period after the 1960s has meant renewed and strengthened assertions of independence on the part of Indians themselves, primarily as a vigorous response against the policies of compensation and termination.

During a concert tour in Sweden in 1978, in support of the effort to end the use of nuclear energy, the Cree singer Buffy Ste. Marie exclaimed: "The proudest thing I can say about my people, is that we exist!" She spoke at a time of heightened awareness of Native American concerns and political activism, following spectacular events such as the occupation of the prison island Alcatraz, off San Francisco, in 1969, the Broken Treaties march across the country in 1972, and the standoff at Wounded Knee on the Pine Ridge reservation in South Dakota in 1973. Yet, it would be false to present Native American activism as a result of 60 s protests:

"Regarding American Indians, the timing is not synchronized completely with other domestic issues. A different drum: lots of local tribal activism, independent of and before civil rights movement. Example: activism among some of the 5 'civilized' Oklahoma tribes including Creeks, to get away from (US) presidentially appointed tribal chiefs. Divisions within some tribes on governance issues."[1]

The compensation and termination programs clearly did not solve problems in Indian country. Negative impact from all sorts of scourges of poverty were and are apparent: unemployment, alcoholism, health problems, AIDS, disruption of families. Native 
Americans themselves have sought to deal with these problems sometimes in cooperation with federal and local offices, but mostly in indigenous ways which distinguish Native activism from that of other groups in American society. What I want to do now is to list some significant new orientations of Native American activism and self-determination and how these create both pride and prejudice.

The latest census count, from 2000, reveals some interesting changes in Indian country, USA. Oklahoma is no longer the state with the largest indigenous population - California is. And the American Indian city is now the city of New York! More than 333,000 people in California defined themselves as only American Indians, while the number for Oklahoma was 273,230. Almost 300,000 Californians and 120,000 Oklahomans claimed to be American Indians as well as some other race. Based on returns who defined themselves by one race alone, the Native American population rose by $26.4 \%$ compared to the census in 1990 to reach 2,475,956 people. If combined with the number of individuals who claimed a mixed heritage the Indian population of the country soared by $110 \%$ to $4,119,301$.

It is too early to state why this increase. However, a few possibilities may be suggested. Indian culture as a presence in American society has become increasingly visible during the decades following the 1960s and may account for the willingness of individuals to lay claim to that heritage, a claim earlier stifled by rampant racism (which is by no means nonexistent today). This awareness has sparked an interest in genealogy that has clarified to more and more people the extent of their native heritage. Powerful issues that emerge today concern battles for respect as indigenous peoples (i.e. protests at the use of demeaning symbols, such as sports mascots), struggles for state and federal recognition, health and education issues, and the preservation of languages.

To many it may appear to be a superficial issue, but to many Native Americans the use of Indian symbols by non-Indians is perceived as demeaning and derogatory. Take the example of the symbols and mascots used by sports teams. In 19951642 sports teams reported using nicknames, mascots, symbols or logos pertaining to American Indians. Most of these were high schools, but they also included 73 college teams and five professional sports teams. As Åse Nygren points out, this use may seem harmless, but many activists, organizations and researchers suggest that it is far from innocent. Instead, they argue that the prevalence of these symbols creates an educational and athletic environment that fosters racial hostility.[2]

Like so many other trends of the 60s protests this is an activism that focuses on cultural issues and identifies in cultural expressions causes of political and economic oppression. Forms of cultural renewal and regeneration are powerful and visible in Native American life in the latter part of the $20^{\text {th }}$ century. One vital expression of cultural renewal is the performance of traditional ceremonies. Albert White Hat, a Blackfoot Indian from Montana, remembered trying to "remake his culture" in the 1970s:

"The ceremonies were still there but people were very hesitant ... When I went back to the tradition ... sweat ceremony, vision quest, Sun Dance ... my own sisters and brother stepped back ... They were deathly scared that I was doing something that was evil...In 1973 I went to a Sun Dance. I remember that for four days they only sang three songs over and over. The next year there were two more. Today there are over twenty sun dance songs that have come back. We did some ceremonies that we read from books. We looked at written documents and tried to follow and as we did the older people would say, "That's not correct," and we went through a lot of criticism in the beginning, but we kept it up and finally one older person got up and said, "Here's how you do it."[3]

This revival of ceremonies did not always involve the knowledge of elders, as Jim Rementer, from Bartlesville, Oklahoma, commented in a response to my question 
concerning changes in Indian country after the 60s: "I guess one thing that I can say from my work with the Delaware Indians is that that was a time when an interest in Indian things and ways developed in the general populace, and then spread to the Indian people. I know of some Indians who were not interested in anything of a traditional nature until the late 60s and early 70s, and all at once they were attending powwows and other Indian functions ... Some of these people were also more aggressive (like the whites) than the more traditional people, and they also had little concept of traditional ways or etiquette."

Indian dancing, in its social and competitive form, has also become a popular part of present-day Indian culture, as well as a tourist attraction. Dancing, an integral part of native cultures (as it is in white cultures), has developed into a pan-Indian practice, fusing elements from various tribal, primarily plains, traditions. Fancy, traditional, jingle, shawl, and grass dances are now performed across the US and Canada, and expert dancers can win large sums at competitions.

Compensation and casinos can thus also illustrate a shift from an economic management originating with federal policies, to a commercialization guided by market demands, a commercialization which involves the marketing of all things Indian. The dancing as a tourist attraction may demonstrate a kind of "catch 22" involving the stereotyping of American Indians. The Indian dancer in full regalia including feathers, moccasins, and facial paint, is still presented as the personification of the "real" Indian, with all its connotations. Indian dancers tour Europe reinforcing the stereotype, in spite of the fact that this is only one part of Native American experiences today. This threatens to hide and deemphasize the many other realities of Native life, such as issues concerning health, education, and political organization. Philip Deloria expresses how both Indians themselves and white people collude in perpetuating this image: "As long as stock-brokers ... open their hearts and their wallets when the mythic Indian pounds on the drum, real Indians will continue to act the part, and their actions will continue to reinforce American symbolic notions. With Indians supporting the framework, non-Indian Americans continue to find it meaningful."[4]

For some Native Americans the frustration over the usage of aspects of Indian culture and symbols out of context, and for economic gain, has led to outraged reactions. In 1993 over 40 representatives of the Lakota tribe issued a "Declaration of war against exploiters of Lakota spirituality," in which they turned against the usage of practices and ceremonies "by non-Indian 'wannabes,' hucksters, cultists, commercial profiteers and self-styled 'New Age shamans' and their followers."[5] However, they also recognized that Lakota Indians themselves were involved in this commercialization of sacred practices.

Native peoples today also seek to revive old ways of organizing politically. As a result of decades of Indian policy designed by Washington, most tribes now have political organizations that clearly resemble those of the non-Indian society. This includes officers, boards of directors, chairmen etc. To many this seems like an alien system, that promotes decision-making techniques that run counter to other values on which they desire to base their communities: "many Indians, especially grass-roots people who live outside the bounds of tribal governments, are beginning to think of ways to re-empower less familiar institutions - the still-existing shadow systems of 'traditional' governance."[6] Institutions that, for example, emphasize consensus decisions and collective rather than individual rights and responsibilities.

Implementing different political institutions, however, requires some form of recognition of Indian status. But successful development toward recognition of more and more bands, both on federal and state levels, is causing rifts between Native groups. As stated in one recent article: "For members of America's 561 federally recognized tribes, the renaissance has been a blessing and a curse. They welcome the renewed respect for Indian culture, but they are angry over the slew of new Indians whom they see as 'wannabes' seeking a share of the $\$ 2.1$ billion in government programs and the lucrative casino gambling industry that has brought wealth to some tribes."[7] This has pitted those with enough documentation to 
join a federally recognized tribe against those who have no choice but to seek membership in state-recognized tribes with less strict requirements.

One reason for the discord can be discerned in the opportunities, and debates, created by the establishment of casinos on Indian-owned land. While recognition does not automatically entail the right to start gambling ventures, this has become a common perception by many who question the recognition of growing numbers of Native groups. The Indian Gaming Act of 1988 meant that "if a state allows certain types of gambling, even for charitable purposes, then it cannot prohibit Indians from conducting the same games for profit."[8] Indians had long taken advantage of the special status of communally owned tribal land as federal trust land to bypass states' regulations on gambling. Highstakes bingo and casinos opened and Indian tribes used the profits to replace some of the moneys lost in government cuts to social services. The first was the Pequot casino, called Foxwood, in Connecticut and the casino has offered job opportunities to both Pequots and local white residents. Its profit is undisclosed but has clearly made the MashantucketPequot nation one of the wealthiest in Ameria. Income from the casino has also funded one of the most modern and exciting new museums anywhere in the United States. Casino gambling has also sparked debates within Indian communities, and some have chosen not to establish casinos as a precaution against addiction within their own tribes.

I used one of the most significant new technologies for Native peoples around the globe the Internet - to ask the question what the upheavals of the sixties meant for Native Americans today. These are some of the answers:

The result of the sixties was that Indian Tribal Governments achieved much more real power. (John Reyhner, Northern Arizona University)[9]

The larger forces of change in America...reached onto Indian reservations and into urban Indian enclaves as had no other time period. Communications, travel, and mass culture shape Indian people as they do everyone else who chooses to be 'wired' to the larger society....Nuclear waste disposal had touched reservations unable to link to these other economic venues. Even the Grammy music awards now recognizes 'Native American music' as one of its categories.... You will get many more suggestions on this list, but you might keep in mind as part of your framework how the larger culture (with its own version of stereotypes and limitations, no matter how well-intentioned or informed) came to Indian country. (Michael Welsh, University of Northern Colorado)[10]

A simple thing like the paving of the roads on this reservation in the last few decades has completely transformed the smaller villages. Now people can commute to jobs or classes. (Prairie Mary Scriver, Montana)[11]

In profound ways Native Americans demand the privilege to disagree with non-Indian American cultural, social, and economic values. One symbol of these different values is the trickster, and to some this trickster character also illustrates what Americans can learn from Indians. Philip Deloria writes: "If Indian people have any great lesson to teach America, it is carried by a trickster history that speaks of the impossibility of holding on to rigid categories of understanding, of the necessity of both uncertainty and conviction, of the true meaning of 'tradition' in a world that will never cease to change ... break down needless and harmful boundaries between people. Empathize. Respect. Become the Other while remaining Yourself."[12]

\section{(C) Gunlög Fur}

[1] Joy Chaudhuri in a personal communication, March 14, 2001.

[2] Åse Nygren, "The Indian Sports Mascot as Cultural Stereotype in the United States and Europe", conference paper at SAAS conference, Stockholm, Oct. 5-7, 2000. 
[3] Quoted in The Native Americans An Illustrated History, ed. by Beth Ballantine and Ian Ballantine (Atlanta: Turner Publishing Company, 1993), p 436

[4] Ibid, p 460.

[5] See i.e. http://www.thepeoplespaths.net/articles/ladecwar.htm, May 18, 2001.

[6] The Native Americans, p 457.

[7] Chicago Tribune, April 4, 2001.

[8] The Native Americans, p 451.

[9] H-net list for American Indian Studies, March 13, 2001

[10] Ibid.

[11] Ibid.

[12] Ibid., p 462. 